\begin{tabular}{c} 
International Journal of Engineering \& Technology, $7(2.4)(2018) 39-45$ \\
International Journal of Engineering \& Technology \\
WPC \\
Website: www.sciencepubco.com/index.php/IJET \\
Research Paper \\
\hline
\end{tabular}

\title{
Cluster head shuffling based global optimization using ele- phant herd optimization (EHO) approach
}

\author{
Er. Sharad ${ }^{1 *}$, Savita Shiwani ${ }^{2}$, Manish Suroliya ${ }^{3}$ \\ ${ }^{1}$ Research Scholar, Dept. of Computer Science and Engineering, Jaipur National University Jaipur \\ ${ }^{2,3}$ Associate Professor, Dept. of Computer Science and Engineering, Jaipur National University Jaipur ${ }^{3}$ Affiliation of the third author \\ *Corresponding author E-mail: chasharad@gmail.com
}

\begin{abstract}
Wireless Sensors are susceptible from frequent energy decay which leads to the reduction of lifetime of entire network scenario. Such energy loss occurring in the sensor nodes are addressed and worked out by number of researchers using number of methods including Lowenergy adaptive clustering hierarchy (LEACH) and its number of variants. Despite of enormous variants of LEACH, there is still huge scope of research because of increasing use of sensor nodes in assorted scenarios. The development of energy aware wireless sensor networks is in research from a long time because of the increasing issues related to lesser lifetime of nodes in the wireless environment. The traditional lifetime of wireless nodes even in smart grids is 835 days while the other wireless nodes die in maximum 30 days. Many times, the battery time of wireless sensor nodes is very few days which is a costly affair. It is difficult and cost consuming to redeploy the wireless nodes to reform the network and cost of clustering. In this research work, a novel and performance aware approach Elephant Herd Optimization based Cluster Head Selection is developed and implemented so that the optimization level can be improved. The nature inspired soft computing approaches are prominently used for global optimization and reduction of error factors from existing results and that is the key focus in this research work.
\end{abstract}

Keywords: Cluster Head Selection in Wireless Networks, Energy Optimization, Elephant Herd Optimization, Wireless Sensor Networks.

\section{Introduction}

Wireless communication [1] involves the transmission and sharing of information in multiple nodes without using the electrical conductor. The wireless communication depends on the radio technology and related assorted aspects for effective and secured data transmission [2].

Modes of Wireless Communication

- Radio

- Optical

- Ultrasonic / Sonic

- $\quad$ Electro Magnetic Induction

There are two separate ways to create the correspondence among various hosts:

"First technique is to use a current cell pecking request which passes on data and also voice; in the phone system, there is a consolidated association or a settled base station which handles coordinating and resource organization routines, since all the directing decisions are made in a bound together way. Therefore these systems are similarly called Infrastructural based systems. Nevertheless the essential issue here is handoff between two zones when customer moves from one cell to other. It transforms into a discriminating to trade data quickly while handoff. Another guideline issue is that it is obliged to the zone where system is accessible.

In the second approach we can structure an ad hoc system among all clients who needs to relate with one another. This proposes all the clients in the astoundingly designated system must be on edge to forward information packs to affirm that the packs are gone on from the source to destination. This sign of systems association is more time than the cell framework and just obliged in the reach by the individual focuses transmission range." It has its own particular perfect circumstances over cell structure and these are:

1. On interest based setup

2. Tolerance with the deficiency and vulnerability

3. Unconstrained network

In programming building and information exchanges, the wireless sensor frameworks are an element examination area with different workshops and joins engineered consistently, for occurrence IPSN and SenSys [3].

\section{Categories \& Standards of Wireless Technology}

- Radio channels with ITU RR

- Radio communication system

- Land Mobile Radio / Professional Mobile Radio

- OpenSky

- TETRA

- DMR

- P25

- EDACS

- dPMR

- Cordless telephony system: DECT (Digital Enhanced Cordless Telecommunications)

- Cellular networks: 0G, 1G, 2G, 3G, Beyond 3G (4G), Future wireless

- $\quad$ Short-range P2P 
- Remote controls

- Wireless microphones

- TransferJet

- IrDA

- RFID

- EnOcean

- Wireless USB

- DSRC

- Near Field Communication

- Wireless sensor networks

- ZigBee

- TransferJet

- Personal area networks

- EnOcean

- Bluetooth

- Ultra-wideband

- Wireless networks

- Wireless LAN (WLAN)

- IEEE 802.11 Wi-Fi and HiperLAN

- LMDS

- Wireless Metropolitan Area Networks (WMAN)

- WiMAX

- HiperMAN

Characteristics of Wireless System

Figure 1.1 depicts the traditional architecture and components associated with the wireless sensor node with the inherent structure.

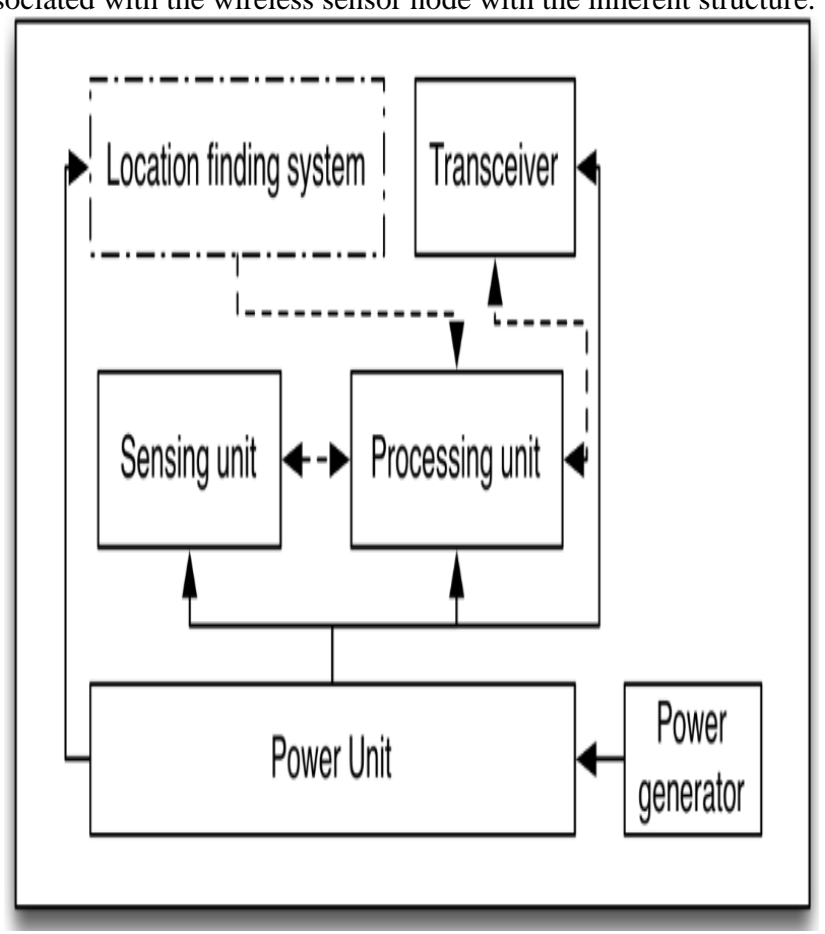

Fig. 1: Classical Format of WSN Node

The key attributes of wireless sensor networks include:

- Utilization of power imperatives for hubs utilizing power devices or vitality reaping

- Capacity to adapt to hub disappointments (strength)

- Versatility of hubs

- Heterogeneity of hubs

- Versatility to huge size of sending

- Capacity to withstand cruel natural conditions

- Convenience

- Cross-layer outline

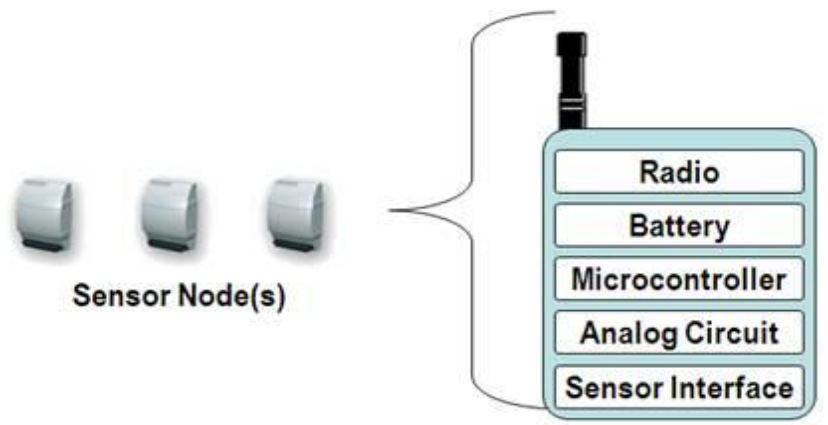

Fig. 2: Internal Aspects of WSN Node

\section{Energy Conversion Mechanism}

This alludes to systems for rummaging electrical energy from a given energy source. The decision of energy transformation component is nearly fixed to the decision of energy source. In the event of sun powered energy, the change system is the utilization of sun oriented boards. A sun oriented board acts like a current source and the measure of current produced is specifically relative to its size/ range and power of episode light. Henceforth, contingent on the prerequisites, greater boards with bigger range or more number of sun based boards are utilized. In the event of mechanical wellsprings of energy like strolling, paddling, pushing catches/keys, change to electrical energy is carried out suing piezo-electric components.

Piezo-electric movies and ceramics endless supply of power and produce electric energy. Bigger the extent of the film, bigger is the measure of energy collected. Wind energy is reaped utilizing rotors and turbines that change over round movement into electrical energy by the rule of electromagnetic impelling.

\section{Approaches for Energy Regain and Harvesting}

In wireless networks, there are mobile nodes which are connected to each other using radio or related transmission line without any physical infrastructure. Wireless Network refers to a specific scenario having mobile nodes connected via mobile routers, base stations or satellites using which the overall network can be controlled and monitored. There are number of applications in which wireless sensor networks are integrated. In classical way, the wireless networks are implemented for the ease of mobility, remote accessibility and cross region connectivity. One of the traditional real life implementation is vehicular ad hoc networks (VANET) [4] in which the vehicles are equipped with wireless devices. In this scenario, the minimum distance of vehicles on road can be measured at run time which reduces the scope of any catastrophe on road .

In WiMax (Worldwide Interoperability for Microwave Access), that is one of the high speed communication of around $40 \mathrm{Mbps}$ is widely used for remote access. It provides high speed integrity based delivery of broadband access to the multiple and remote locations.

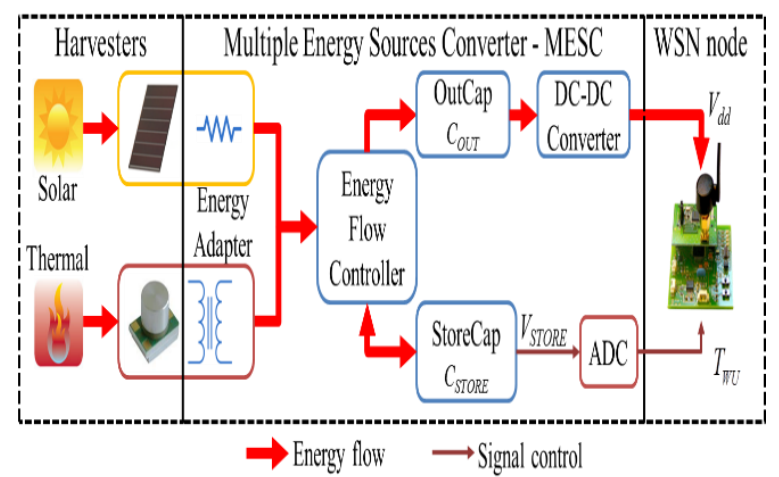

Fig. 3: Energy Optimization in Wireless System 


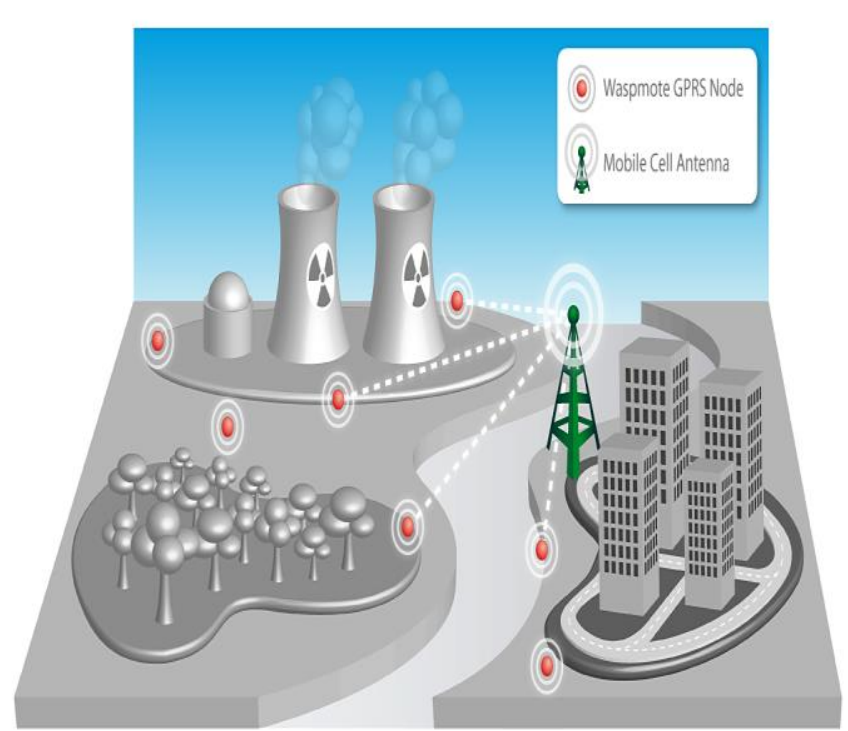

Fig. 4: Traditional Scenario of Wireless Sensor Networks

The key attribute of a Wireless Network comprises

Source - $\quad$ Source Node (Mote)

$\mathrm{CH} \quad-\quad$ Cluster Head (Aggregator)

BS - $\quad$ Base Station (Tower)

\section{Key Attributes of Wireless Network}

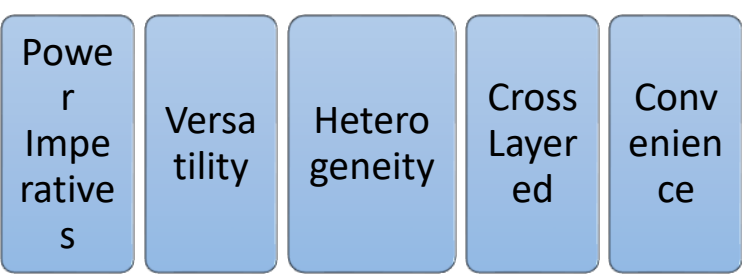

Fig. 5: Key Attributes of Wireless Sensor Networks

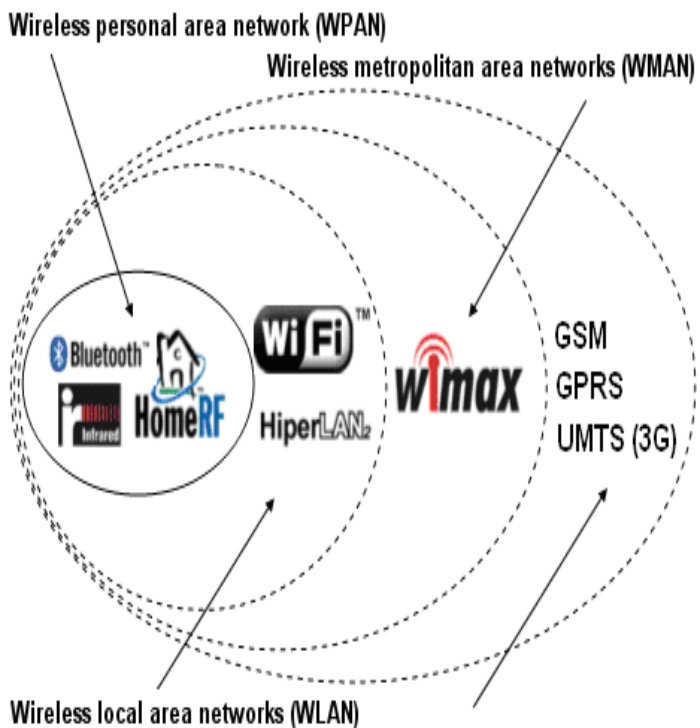

Wireless wide area networks MWAN

Fig. 6: Taxonomy of Wireless Technologies

Following table underlines the comparative analysis of wireless standards on assorted parameters and factors. By this aspect, the deep review on the protocol based analysis can be done.
Table 1: Comparative Pragmatic Analysis of Wireless based Standards

\begin{tabular}{|c|c|c|c|c|c|}
\hline & $\begin{array}{l}\text { Blue- } \\
\text { tooth }\end{array}$ & $\begin{array}{l}\text { Wi-Fi } \\
\text { (a) }\end{array}$ & $\begin{array}{c}\text { Wi-Fi } \\
\text { (b) }\end{array}$ & $\begin{array}{c}\text { Wi-Fi } \\
\text { (g) }\end{array}$ & $\begin{array}{c}\text { Wi- } \\
\text { MAX }\end{array}$ \\
\hline $\begin{array}{c}\text { Interna- } \\
\text { tional } \\
\text { Standard }\end{array}$ & 802.15 & $802.11 \mathrm{a}$ & $802.11 b$ & $802.11 \mathrm{~g}$ & 802.16 \\
\hline $\begin{array}{c}\text { Fre- } \\
\text { quency } \\
\text { (GigaHz) }\end{array}$ & 2.5 & 5 & $\begin{array}{l}\text { More } \\
\text { than } 2\end{array}$ & 2.4 & $2-66$ \\
\hline $\begin{array}{c}\text { Speed } \\
(\mathrm{Mbps})\end{array}$ & $\begin{array}{c}\text { Around } \\
1 \\
\end{array}$ & 54 & 11 & $\begin{array}{c}\text { More } \\
\text { than } 50\end{array}$ & $\begin{array}{c}\text { Around } \\
100\end{array}$ \\
\hline $\begin{array}{l}\text { Range Pa- } \\
\text { rameter } \\
(\mathrm{mt})\end{array}$ & 10 & $\begin{array}{l}\text { More } \\
\text { than } 50\end{array}$ & $\begin{array}{l}\text { More } \\
\text { than } 80\end{array}$ & $\begin{array}{c}\text { More } \\
\text { than } 100\end{array}$ & $\begin{array}{l}\text { More } \\
\text { than } 50\end{array}$ \\
\hline $\begin{array}{c}\text { Ad- } \\
\text { vantages }\end{array}$ & $\begin{array}{l}\text { Low } \\
\text { Cost }\end{array}$ & Speed & $\begin{array}{l}\text { Less } \\
\text { Cost }\end{array}$ & Speed & Range \\
\hline $\begin{array}{c}\text { Limita- } \\
\text { tions }\end{array}$ & $\begin{array}{l}\text { Range } \\
\text { Issues }\end{array}$ & $\begin{array}{l}\text { Cost } \\
\text { Factor }\end{array}$ & Speed & $\begin{array}{c}\text { Cost and } \\
\text { Range } \\
\text { both }\end{array}$ & Cost \\
\hline
\end{tabular}

Table 2: Comparison between WSN and Mobile Ad Hoc Networks

\begin{tabular}{|l|l|}
\hline $\begin{array}{l}\text { WIRELESS SENSOR NET- } \\
\text { WORKS }\end{array}$ & $\begin{array}{l}\text { MOBILE AD HOC NET- } \\
\text { WORKS }\end{array}$ \\
\hline $\begin{array}{l}\text { Energy Consumption more and } \\
\text { generally non rechargeable due to } \\
\text { remote and sensitive locations }\end{array}$ & $\begin{array}{l}\text { Energy is not the issue because of } \\
\text { recharging }\end{array}$ \\
\hline $\begin{array}{l}\text { Very far and not accessible physi- } \\
\text { cally in general }\end{array}$ & $\begin{array}{l}\text { More close of Human Experts / } \\
\text { Users }\end{array}$ \\
\hline Data Aggregation / Grouping & No need of aggregation \\
\hline Clustering & $\begin{array}{l}\text { Each mobile node act as router it- } \\
\text { self }\end{array}$ \\
\hline $\begin{array}{l}\text { Security and Integrity are the key } \\
\text { issues }\end{array}$ & $\begin{array}{l}\text { Security is not an issue as it is al- } \\
\text { ways very close to human user }\end{array}$ \\
\hline
\end{tabular}

Types of Wireless Networks

- Cellular Network

- Global Area Network

- Wireless PAN

- Wireless LAN

- Wireless Mesh Network

- $\quad$ Space Network

- Wireless MAN

- Wireless WAN

Features of Wireless Networks

- Multi-hop Routing

- Dynamic and Effective Load Balancing

- Network Access Control

- Autonomous

- Distributed Operation

- Dynamic Network Topology

- Network Scalability

- Light Weight Terminals

- Scalability

- $\quad$ Speed of deployment

- Decreased dependence on infrastructure

- Mobility and Quality of Service

- Portability and Transportation

Energy Consuming Attacks in Wireless Networks 


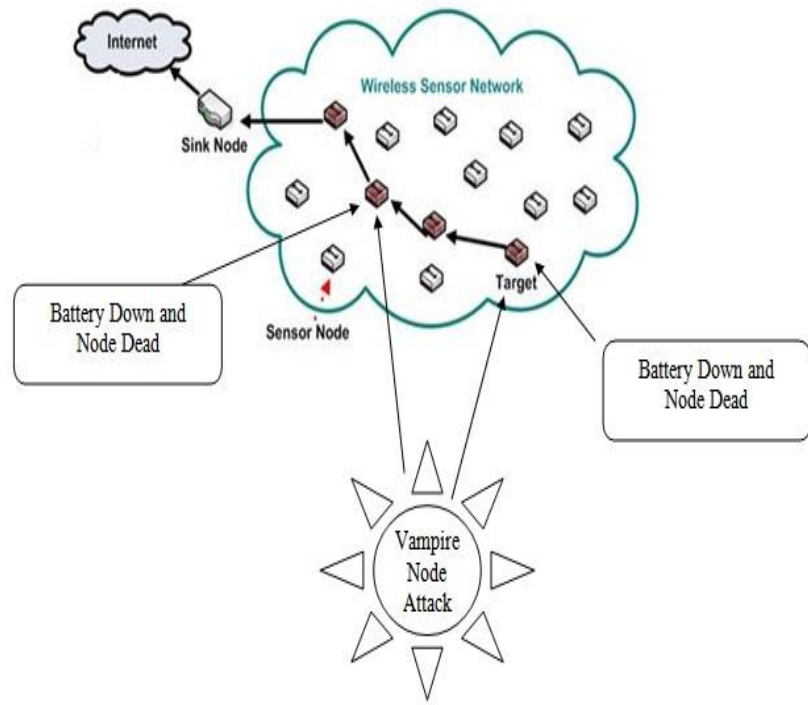

Fig. 7: Wicked WiMax Node Attack consuming the Battery of Sensor Nodes

Figure depicts the modus operandi of wicked nodes attack on the wi-max environment. One of the vital parts of Wicked WiMax Node Attack [5] is that it is convention free. It implies the Wicked WiMax Node assaults can work and harm of any kind of system.
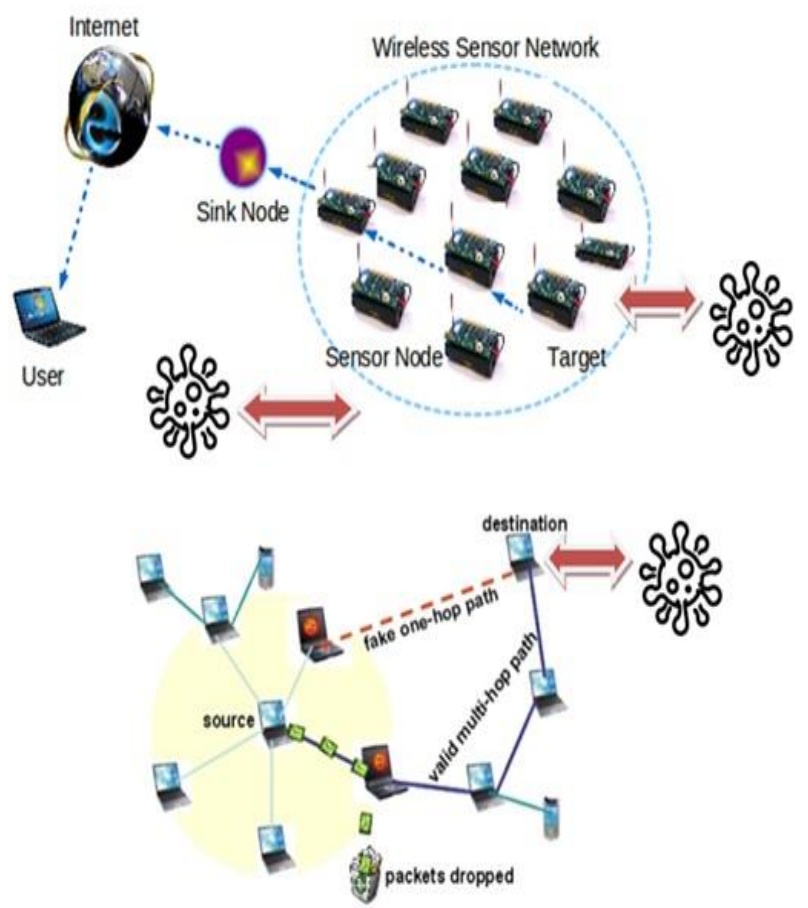

Fig. 8: Intrusion of Wicked WiMax Node Nodes in the Wireless Network

- Wicked WiMax Node attacks are not specific to any protocol or topology or port.

- Wicked WiMax Node Attacks do not interrupt the services directly. It affects the resources using the services.

- Wicked WiMax Nodes makes use of protocol compatible or compliant messages

- Wicked WiMax Node Attacks transmit data that drain the energy level of nodes.

- Wicked WiMax Nodes do not change or interrupt altering discovered paths or routes.

Resource Draining Attacks - Such attacks create and send Wicked WiMax Node attack means creating and sending messages by malicious node which causes more energy consumption by the network leading to slow depletion of node's battery life.

The Wicked WiMax Node attacks in the resource draining assaults can be classified has two types.

- Carousel attack

- $\quad$ Stretch attack.

In the following figure there is the depiction of Carousal Attack. In the Carousel attack, attackers intrude a specific packet within a route as sequence of loops, so that the same node execute in the route of communication many times. This type of attack drastically increases the routing path and length which creates delay in the networks and also inadequate by the number of allowable entries in the resource route.

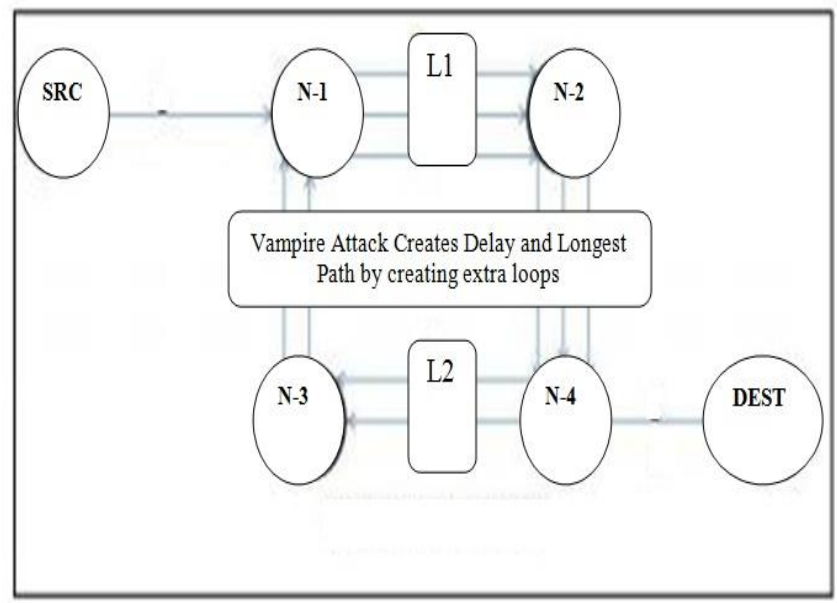

Fig. 9: Carousal Attack

Following is the figure underlining the Stretch Attack. Adversary constructs artificially long routes traversing every node in the network that causes packets to traverse larger than optimal no of nodes. This attack causes the node that doesn't lie on optimal path to process packets. Such attacks are potentially less damaging per packet than the carousel attack, as the no of hops per packet is bounded by the number of network nodes.

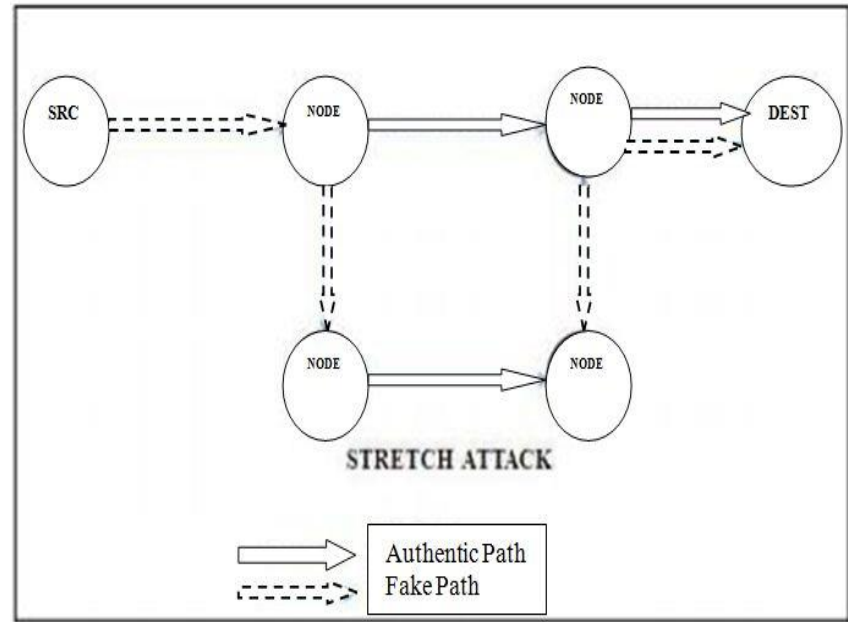

Fig.10: Stretch Attack - A Scenario of Wicked WiMax Node Assault

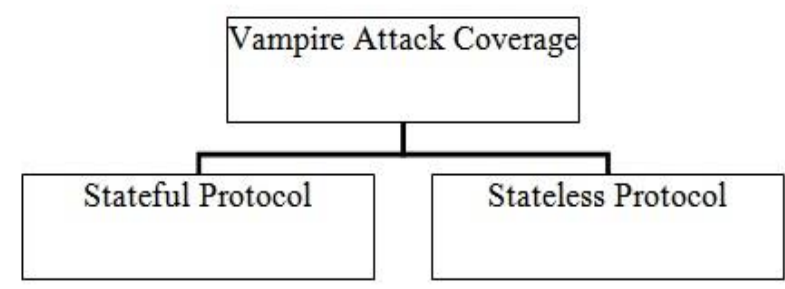

Fig. 11: Taxonomy of Wicked WiMax Node Assaults Coverage 
As in Figure, there is the taxonomy of vampire or wicked node attacks which should be avoided in prior so that the security cannot be breached.

\section{Extracts of Literature}

A number of researchers and practitioners have worked on the analysis of remote sensor technology and energy optimization but there is huge scope for the improvement in cases where energy aware data transmission and integrity is necessary due to huge requirements of confidentiality \& integrity with greater degree of accuracy. A number of research papers and manuscripts are analyzed from the time span of (2015-2017) so that the latest trends in energy optimization and lifetime of wireless sensor networks can be evaluated.

\begin{tabular}{|c|c|c|c|}
\hline Author(s) & Year & Work Done & Advantages \\
\hline $\begin{array}{l}\text { G. Rama Subba } \\
\text { Reddy et al. }\end{array}$ & 2017 & $\begin{array}{l}\text { Effectual Review of Clustering and Energy Optimi- } \\
\text { zation dimensions in Wireless Sensor Networks }\end{array}$ & $\begin{array}{l}\text { Deep evaluation of the architectures and protocols } \\
\text { prevalent and adopted by the academicians and re- } \\
\text { searchers for energy optimization and harvesting in } \\
\text { wireless sensor networks }\end{array}$ \\
\hline $\begin{array}{l}\text { Rahimeh } \\
\text { Ghasemzadeh et } \\
\text { al. }\end{array}$ & 2017 & $\begin{array}{l}\text { Development and Implementation of a new algo- } \\
\text { rithm SFLA LEACH for energy optimization and } \\
\text { overall effectiveness in the wireless networks }\end{array}$ & $\begin{array}{l}\text { The proposed architecture and protocols provide the } \\
\text { higher lifetime and accuracy in the wireless sensor net- } \\
\text { work environment. The novel approach is presented } \\
\text { with better results as compared to LEACH, WEEC, } \\
\text { BN-LEACH, GA-LEACH and related variants }\end{array}$ \\
\hline $\begin{array}{l}\text { Arzoo Miglani et } \\
\text { al. }\end{array}$ & 2017 & $\begin{array}{l}\text { Proposed a novel approach Energy Aware and Trust } \\
\text { Aware (EETA-LEACH) for improving the lifetime } \\
\text { and overall performance of wireless sensor networks }\end{array}$ & $\begin{array}{l}\text { The work is related to energy optimization as well as } \\
\text { security to repel back the malicious nodes so that the } \\
\text { energy cannot be consumed by wicked nodes. The } \\
\text { work focus on the trust based routing module as well } \\
\text { as trust based energy optimization in wireless environ- } \\
\text { ment. The dying time in EETA-LEACH is quite de- } \\
\text { layed to improve the overall lifetime of network envi- } \\
\text { ronment }\end{array}$ \\
\hline $\begin{array}{l}\text { Paola G. Vinueza } \\
\text { Naranjo et al. }\end{array}$ & 2017 & $\begin{array}{l}\text { Devised a new approach Prolong Stable Election } \\
\text { Protocol (P-SEP) to improve the energy aware rout- } \\
\text { ing in wireless networks. }\end{array}$ & $\begin{array}{l}\text { The proposed P-SEP is giving better results as com- } \\
\text { pared to DCHS-LEACH AND M-SEP in terms of } \\
\text { longer lifetime, minimum packets loss and higher de- } \\
\text { gree of performance for multiple nodes in the wireless } \\
\text { environment. The work effectually presents the associ- } \\
\text { ation and effectiveness in fog computing which is one } \\
\text { of the research areas for wireless environment. }\end{array}$ \\
\hline K. Vijayan et al. & 2016 & $\begin{array}{l}\text { Energy Aware and Load Balanced approach } \\
\text { Cluster Arrangement Energy Efficient Routing Pro- } \\
\text { tocol (CAERP) is proposed and implemented to es- } \\
\text { calate the dynamic cluster formation in the wireless } \\
\text { network environment and overall lifetime of the } \\
\text { wireless sensor nodes }\end{array}$ & $\begin{array}{l}\text { The proposed CAERP is having four modules Dy- } \\
\text { namic Clustering, Cluster Head (CH) Selection, Effec- } \\
\text { tive Routing and Energy Aware Secured Data Commu- } \\
\text { nication. The results compared to Q-LEACH are en- } \\
\text { hanced with higher survival rate and minimum average } \\
\text { energy consumption. }\end{array}$ \\
\hline $\begin{array}{l}\text { Hamid Ali Abed } \\
\text { Alasadi }\end{array}$ & 2016 & $\begin{array}{l}\text { Developed the performance aware approach } \\
\text { Energy Efficient Hierarchical Clustering Mecha- } \\
\text { nism (EEHCM) for residual energy management } \\
\text { and survival of nodes }\end{array}$ & $\begin{array}{l}\text { The hierarchical clustering based approach is giving } \\
\text { better results as compared to traditional LEACH. The } \\
\text { projected approach takes care of communication cost, } \\
\text { residual energy and distance matrix with the base sta- } \\
\text { tion to escalate the overall lifetime. }\end{array}$ \\
\hline $\begin{array}{l}\text { Muhammad Ta- } \\
\text { hir, Fazlullah } \\
\text { Khan et al. }\end{array}$ & 2016 & $\begin{array}{l}\text { Derived and simulated an energy aware model EEC } \\
\text { for frequent evaluation and deep analytics of the en- } \\
\text { ergy consumption taking place in wireless sensor } \\
\text { networks }\end{array}$ & $\begin{array}{l}\text { The choice of nodes and clustering protocols are taken } \\
\text { care in the wireless environment so that the overall } \\
\text { performance and lifetime of the nodes can be im- } \\
\text { proved. }\end{array}$ \\
\hline Basma Fathi et al. & 2016 & $\begin{array}{l}\text { A novel approach integrating K-Means Clustering } \\
\text { and Particle Swarm Optimization (KPSO) is pre- } \\
\text { sented for higher degree of optimization and effec- } \\
\text { tual results. }\end{array}$ & $\begin{array}{l}\text { KPSO provides the optimization and harvesting as- } \\
\text { pects with traditional LEACH. The hybrid approach } \\
\text { KPSO is presented with more than } 40 \% \text { better as com- } \\
\text { pared to the classical approach. }\end{array}$ \\
\hline Asgarali Bouyer & 2015 & $\begin{array}{l}\text { The energy aware and performance focused ap- } \\
\text { proach Fuzzy C-Means (FCM) is developed with } \\
\text { simulation model }\end{array}$ & $\begin{array}{l}\text { The results compared with traditional LEACH are bet- } \\
\text { ter and giving higher lifetime to the network. }\end{array}$ \\
\hline $\begin{array}{l}\text { Gopi Saminathan } \\
\text { Arumugam et al. }\end{array}$ & 2015 & $\begin{array}{l}\text { The authors devised a novel Energy Efficient } \\
\text { LEACH (EE-LEACH) to integrate the energy aware } \\
\text { routing with minimum packets loss and greater de- } \\
\text { gree of lifetime in the wireless nodes }\end{array}$ & $\begin{array}{l}\text { The concept is based on the forwarding of nodes hav- } \\
\text { ing specific residual energy so that selected cluster } \\
\text { heads can lead the overall network with higher degree } \\
\text { of accuracy }\end{array}$ \\
\hline $\begin{array}{l}\text { Amjad Mehmood } \\
\text { et al. }\end{array}$ & 2015 & $\begin{array}{l}\text { The integration of Vice Cluster Head for Energy } \\
\text { Optimization in Wireless Sensor Networks }\end{array}$ & $\begin{array}{l}\text { Integration and implementation of a new cluster head } \\
\text { titled vice cluster head (VCH) so that the backup or } \\
\text { candidate node for cluster head can be available with- } \\
\text { out any delay in case of failure of cluster head }\end{array}$ \\
\hline $\begin{array}{l}\text { Mustapha Khiati } \\
\text { et al. }\end{array}$ & 2015 & $\begin{array}{l}\text { Effective Approach titled Broadcast over Duty-Cy- } \\
\text { cle and LEACH } \\
\text { (BOD-LEACH) is presented and developed for im- } \\
\text { provements in the overall communication and mini- } \\
\text { mization of latency in wireless environment }\end{array}$ & $\begin{array}{l}\text { The broadcast path takes care of the base station and } \\
\text { valid communication lines so that the channel cannot } \\
\text { be under choke situation and energy can be optimized } \\
\text { with higher lifetime }\end{array}$ \\
\hline
\end{tabular}

\section{Inferences Drawn from Literature}

There is huge scope of escalation in traditional LEACH because of increasing use of wireless nodes in the smart grid and high performance applications including energy aware secured networks. With the integration of nature inspired algorithms, the performance of classical LEACH can be escalated and such algorithms are not widely implemented so far in association of LEACH. 


\section{Problem Identification}

LEACH is one of the prominent approaches for energy aware routing in Wireless Networks, still this approach is under research because of escalating assaults and energy consuming assails. In this research work, the need to devise and implement a new and effectual approach with variant of LEACH is proposed with title NIA LEACH which refers to nature inspired algorithm based LEACH. By this approach, the overall optimization factors can be enhanced with higher degree of accuracy and performance.

\section{Approach, Results and Discussion}

There are many procedures to select the cluster head based on the criteria

- $\quad$ Male and Female Optimization Approaches in EHO

- Battery power and Optimization Strategies based on EHO

- Communication range as per Signals Transmission in Objects

- Position of the node and Lifetime

- Total number of nodes in range

- Mobility of the node

The access nodes and other wireless nodes shall be considered as Female and Male Elephants. Every node shows its identity to other nodes in that group by creating handshake message. This message reaches the node which is already registered under cluster head of some other group, that node declares itself as the Access Node (AN) and announces its presence to the node initiated the handshake message, it also shares the common identifier with that node. Normal nodes, Access Node and Cluster head are belong to the one group, so each group contain these three types of nodes.

\section{BEGIN}

Initialize nodes and Activation as Elephant Object

Initialize source and destination nodes with Random Energy Parameters and Threshold

FOR $i=0$ to $n D O$

$\mathrm{CH}_{i} \leftarrow$ Nodes with higher battery power, abil-

ity to manage other nodes

IF (nodes in range of $\mathrm{CH}$ ) THEN

Transmit common identifier

Integration of Nature Inspired Ap-

proach Module 1

$$
\begin{gathered}
\text { ELSE } \\
\text { END IF node is under other } C H \\
\text { END FOR } \\
\text { FOR } i=0 \text { to } n \text { DO } \\
\text { IF (source node and destination node is under }
\end{gathered}
$$

same CH) THEN

destination node

proach Module 2

$$
\text { ELSE }
$$

\section{Forward RREQ $\rightarrow$}

Integration of Nature Inspired Ap-

$$
\begin{aligned}
& \text { Forward RREQ } \rightarrow \mathrm{CH}_{i} \\
& \mathrm{CH}_{\boldsymbol{i}} \rightarrow \mathrm{BS}_{i} \mathrm{BS}_{\boldsymbol{i}} \rightarrow \mathrm{CH}_{i} \\
& \mathrm{CH}_{i} \rightarrow \text { destination node }
\end{aligned}
$$

Threshold Evaluation and Fitness of

Results

\section{END IF}

END FOR

END FOR

END

The proposed novel approach using nature inspired algorithm is implemented using Network Simulator ns3 with the integration of netanim. The dynamic clustering and allocation of cluster head is implemented with dynamic number of nodes with varying random energy levels.

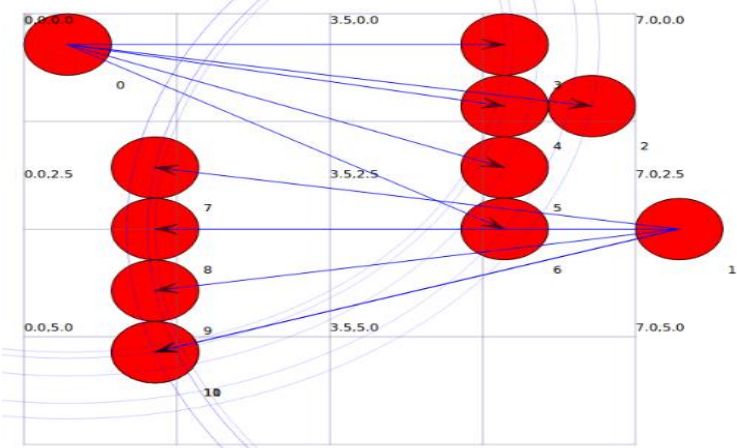

Fig. 12: Dynamic Positions of Sensor Nodes in Network Simulator

\begin{tabular}{rrrr}
\hline $\begin{array}{c}\text { Network } \\
\text { Scenario }\end{array}$ & $\begin{array}{l}\text { Energy Consumed - } \\
\text { Traditional LEACH }\end{array}$ & $\begin{array}{l}\text { Energy Consumed - Tradi- } \\
\text { tional EHO-LEACH }\end{array}$ \\
\hline 1 & 80 & 20 \\
2 & 78 & 35 \\
3 & 69 & 43 \\
4 & 87 & 24 \\
5 & 68 & 24 \\
\hline
\end{tabular}

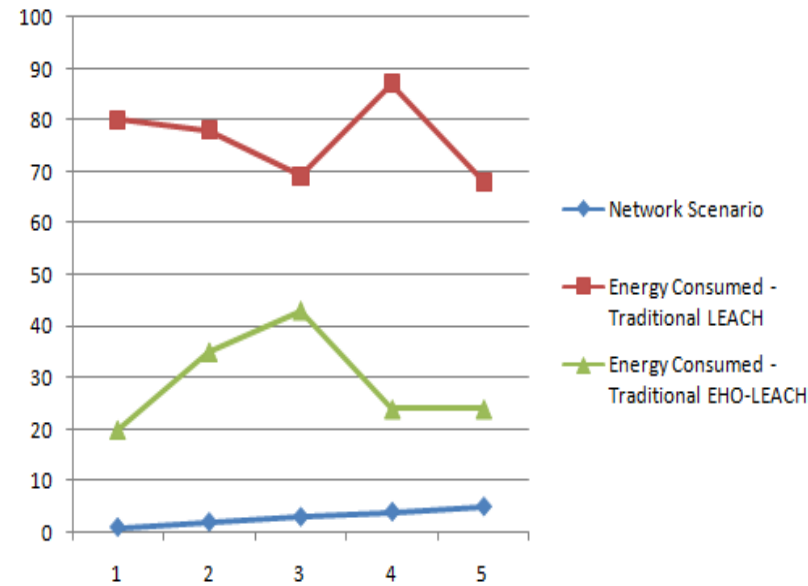

Fig. 13: Comparative Evaluation of Traditional and Projected Soft Computing Approach

\begin{tabular}{llllr}
\hline $\begin{array}{l}\text { Network } \\
\text { Scenario }\end{array}$ & $\begin{array}{l}\text { Performance - Tradi- } \\
\text { tional LEACH }\end{array}$ & \multicolumn{2}{c}{$\begin{array}{l}\text { Performance - EHO- } \\
\text { LEACH }\end{array}$} \\
\hline & 1 & 40 & 57 \\
2 & 43 & 67 \\
& 3 & 53 & 68 \\
4 & 23 & 76 \\
5 & 42 & 87 \\
\hline
\end{tabular}

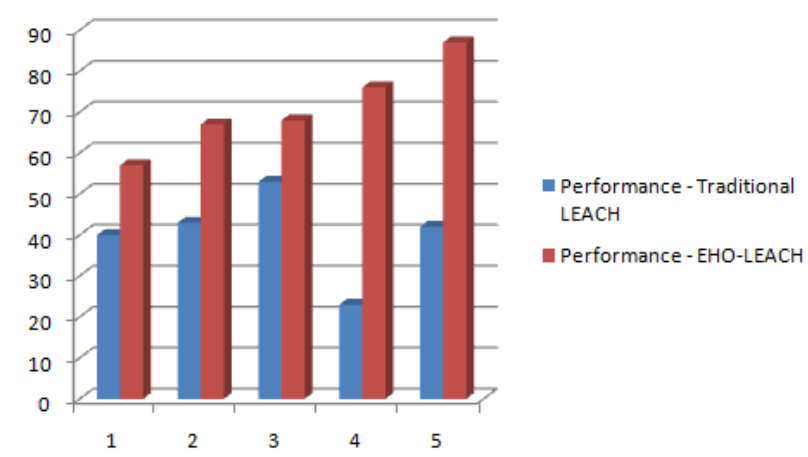

Figure 14 - Comparative Evaluation of Traditional and Projected Soft Computing Approach 


\section{Conclusion}

The proposed approach is having higher degree of lifetime, accuracy and overall optimization factors. Nature Inspired Approaches are widely used for solving optimization problems from a long time and that's why this dimension is adopted to be implemented in the wireless networks. The proposed approach is evaluated on multiple parameters including energy optimized, accuracy, turnaround time and overall performance of the network. In this proposed algorithm, efficient routing technique is meant to be followed by various sensor nodes with the help of cluster Heads. The wireless nodes with degree of energy and lifetime are given occasion to be cluster head so that overall performance and lifetime of the clustered environment can be escalated.

\section{References}

[1] Tse D, Viswanath P. Fundamentals of wireless communication. Cambridge university press; 2005 May 26.

[2] Kakkar A, Singh DM, Bansal DP. Efficient key mechanisms in multinode network for secured data transmission. International Journal of Engineering Science and Technology. 2010;2(5):787-95.

[3] Camp T, Rubin MJ, Gonzalez S. Challenges in Developing Intelligent Geosystems (and the pros/cons of interdisciplinary research). InComputing, Networking and Communications (ICNC), 2015 International Conference on 2015 Feb 16 (pp. 591-597). IEEE.

[4] Hartenstein H, Laberteaux LP. A tutorial survey on vehicular ad hoc networks. IEEE Communications magazine. 2008 Jun;46(6).

[5] Anand J, Sivachandar K. Vampire Attack Detection in Wireless Sensor Network. International Journal of Engineering Science and Innovative Technology (IJESIT) Volume. 2014 Jul;3.

[6] Ghasemzadeh R, Latif A. Improving LEACH Protocol Using SFLA Algorithm to Reduce the Energy Consumption of Wireless Sensor Networks. International Journal of Scientific Engineering and Technology. 2017;6(7):255-9.

[7] Reddy GR, Balaji S. A Review on Different Types of LEACH Protocol for Wireless Sensor Networks.

[8] Naranjo PG, Shojafar M, Mostafaei H, Pooranian Z, Baccarelli E. PSEP: a prolong stable election routing algorithm for energy-limited heterogeneous fog-supported wireless sensor networks. The Journal of Supercomputing. 2017 Feb 1;73(2):733-55.

[9] Miglani A, Bhatia T, Sharma G, Shrivastava G. An Energy Efficient and Trust Aware Framework for Secure Routing in LEACH for Wireless Sensor Networks. Scalable Computing: Practice and Experience. 2017 Sep 9;18(3):207-18.

[10] Vijayan K, Raaza A. A novel cluster arrangement energy efficient routing protocol for wireless sensor networks. Indian Journal of science and Technology. 2016 Feb 5;9(2).

[11] Alasadi HA. Energy Efficient Hierarchical Clustering Mechanism for Wireless Sensor Network Fields. International Journal of Computer Applications. 2016;153(8).

[12] Tahir M, Khan F, Jan SR, Azim N, Khan IA, Ullah F. EEC: Evaluation of Energy Consumption in Wireless Sensor Networks. International Journal of Engineering Trends and Applications, ISSN. 2016:2393-9516

[13] SOLAIMAN B. Energy optimization in wireless sensor networks using a hybrid k-means pso clustering algorithm. Turkish Journal of Electrical Engineering \& Computer Sciences. $2016 \mathrm{Apr}$ 15;24(4):2679-95

[14] Bouyer A, Hatamlou A, Masdari M. A new approach for decreasing energy in wireless sensor networks with hybrid $\mathrm{LEACH}$ protocol and fuzzy C-means algorithm. International Journal of Communication Networks and Distributed Systems. 2015;14(4):400-12.

[15] Arumugam GS, Ponnuchamy T. EE-LEACH: development of energy-efficient LEACH Protocol for data gathering in WSN. EURASIP Journal on Wireless Communications and Networking. 2015 Mar 20;2015(1):76.

[16] Mehmood A, Mauri JL, Noman M, Song H. Improvement of the Wireless Sensor Network Lifetime Using LEACH with Vice-Cluster Head. Ad Hoc \& Sensor Wireless Networks. 2015 Aug;28(1-2):1-7.

[17] Khiati M, Djenouri D. BOD-LEACH: broadcasting over duty-cycled radio using $\mathrm{LEACH}$ clustering for delay/power efficient dissimilation in wireless sensor networks. International Journal of Communication Systems. 2015 Jan 25;28(2):296-308. 